\title{
Apoptosis induced by ursodeoxycholic acid in human melanoma cells through the mitochondrial pathway
}

\author{
HUAN YU ${ }^{1 *}$, QI-RUI FU ${ }^{1 *}$, ZHI-JIE HUANG ${ }^{1}$, JIA-YU LIN $^{1}$, QING-XI CHEN ${ }^{1}$, \\ QIN WANG ${ }^{1}$ and DONG-YAN SHEN ${ }^{2}$ \\ ${ }^{1}$ Key Laboratory of The Ministry of Education for Coastal and Wetland Ecosystems, \\ School of Life Sciences, Xiamen University, Xiamen, Fujian 361005; \\ ${ }^{2}$ Department of Biobank, The First Affiliated Hospital of Xiamen University, \\ Xiamen, Fujian 361003, P.R. China
}

Received May 18, 2018; Accepted October 10, 2018

DOI: $10.3892 / o r .2018 .6828$

\begin{abstract}
Ursodeoxycholic acid (UDCA) is a type of hydrophilic bile acid extracted from animal bile with a wide range of biological functions. The present results demonstrated that UDCA could effectively inhibit the proliferation of two human melanoma cell line (M14 and A375) with time- and concentration-dependence. Following exposure to various concentrations of UDCA, M14 cells exhibited typical morphological changes and weaker ability of colony forming. Flow cytometry analysis demonstrated that UDCA could induce a decrease of mitochondrial membrane potential and an increase in reactive oxygen species (ROS) levels in M14 cells. The cell cycle was arrested in the G2/M phase, which was confirmed by the decrease of cyclin-dependent kinase 1 and cyclinB1 at the protein level. However, when M14 cells were treated with UDCA and Z-VAD-FMK (caspase inhibitor) synchronously, the apoptosis rate of the cells was reduced significantly. In addition, it was demonstrated that UDCA induced apoptosis of human melanoma M14 cells through the ROS-triggered mitochondrial-associated pathway, which was indicated by the increased expression of cleaved-caspase-3, cleaved-caspase-9, apoptotic protease activating factor-1, cleaved-poly (ADP-ribose) polymerase 1 and the elevation of B cell lymphoma-2 (Bcl-2) associated $\mathrm{X}$ protein/Bcl-2 ratio associated with apoptosis. Therefore, UDCA may be a potential drug for the treatment of human melanoma.
\end{abstract}

Correspondence to: Dong-Yan Shen, Department of Biobank, The First Affiliated Hospital of Xiamen University, 55 Zhenhai Road, Xiamen, Fujian 361003, P.R. China

E-mail: shendongyan@163.com

Qin Wang, School of Life Sciences, Xiamen University, Xiang'an District, Xiamen 361102, P.R. China

E-mail: qwang@xmu.edu.cn

*Contributed equally

Key words: ursodeoxycholic acid, apoptosis, melanoma, mitochondria, reactive oxygen species, mitochondrial membrane potential

\section{Introduction}

Ursodeoxycholic acid (UDCA) is a type of hydrophilic bile acid that is produced by intestinal bacteria and accounts for only $4 \%$ of total bile acids in humans (1). UDCA has been reported to reduce the concentration of eosinophilic bile acids in bile acids and serum, as well as tumor necrosis factor- $\alpha$ in chronic cholestasis (2). Unlike toxic hydrophobic bile acids acting as carcinogens in various organs (the liver, colon and gastrointestinal tract), hydrophilic bile acids have long been considered as tumor suppressors for hepatocellular and colon cancer, as well as a reducer of cholestatic liver diseases (3-7). However, it remains unclear whether UDCA could suppress the growth of human melanoma.

Melanoma is the deadliest form of skin cancer and the incidence of melanoma in the population has increased steadily in recent years: According to the World Health Organization, there are 132,000 cases of cutaneous melanoma worldwide each year (8), and according to statistics from the American Cancer Society, $\sim 9,730$ people succumbed to melanoma in the United States in $2017(9,10)$. The high mortality in melanoma patients has prompted novel research on therapies and drugs that increase efficacy, but the long-term survival of melanoma patients remains poor $(11,12)$. Therefore, there is an urgent need to identify novel therapeutic agents or novel therapeutic strategies to improve the outcome of patients with advanced melanoma.

Apoptosis serves an important role in the normal development and differentiation of multicellular organisms $(13,14)$. Activation of apoptosis in cancer cells may contribute to the elimination of cancer cells. The extrinsic and intrinsic pathways are the two major pathways regulating apoptosis, which are also known as death receptor pathways and mitochondrial pathways $(13,15)$. Mitochondria are two-layered membrane organelles that are present in cells, and are the main organelles that maintain homeostasis within cells and the main site for aerobic respiration of cells (16). The destruction of mitochondria is an important feature of apoptosis. Cytoplasmic contraction, extensive plasma membrane blistering and nuclear condensation are the morphological features of apoptosis, which develops in a caspase-dependent or caspase-independent manner $(17,18)$. In addition, the ratio 
of anti-apoptosis and pro-apoptotic mitochondrial proteins B cell lymphoma-2 (Bcl-2) associated X protein (Bax)/Bcl-2 determine the susceptibility of cells to apoptosis (19).

In the present study, UDCA suppressed the growth of M14 cells and induced apoptosis through mitochondrial-associated apoptosis pathways, indicating that UDCA may become a potential agent for the treatment of human melanoma.

\section{Materials and methods}

Reagents. Dulbecco's modified Eagle's medium (DMEM), trypsin-EDTA, fetal bovine serum (FBS), penicillin and streptomycin were obtained from Gibco; Thermo Fisher Scientific, Inc. (Waltham, MA, USA). MTT, dimethyl sulfoxide (DMSO), Hoechst 33258, acridine orange/ethidium bromide (AO/EB), Annexin V-fluorescein isothiocyanate (FITC)/propidium iodide (PI) apoptosis detection kit, Cell Mitochondria Isolation kit, JC-1, cell cycle assay kit, PI and caspase inhibitor Z-VAD-FMK were purchased from Sangon Biotech Co., Ltd. (Shanghai, China). UDCA, radioimmunoprecipitation assay buffer and protease inhibitor were purchased from Sigma-Aldrich; Merck KGaA (Darmstadt, Germany). Antibodies were purchased from the following sources: Actin (1:10,000; mouse polyclonal; cat. no. 60008-1-Ig), $\operatorname{Bax}(1: 1,000$; rabbit polyclonal; cat. no. 50599-2-Ig), Bcl-2 (1:1,000; rabbit polyclonal; cat. no. 12789-1-Ig), cyclin-dependent kinase (CDK)1 (1:1,000; rabbit polyclonal; cat. no. 19532-1-AP), cyclinB1 (1:1,000; rabbit polyclonal; cat. no. 55004-1-AP), p21 (1:1,000; rabbit polyclonal; cat. no. 10355-1-AP), matrix metalloproteinase (MMP)-2 (1:1,000; rabbit polyclonal; cat. no. 10373-2-AP), caspase-9 (1:1,000; rabbit polyclonal; cat. no. 10380-1-AP), MMP-9 (1:1,000; rabbit polyclonal; cat. no. 10375-2-AP), caspase-3 (1:1,000; rabbit polyclonal; cat. no. 19677-1-AP), p53 (1:1,000; rabbit polyclonal; cat. no. 10442-1-AP), poly (ADP-ribose) polymerase (PARP)1 (1:1,000; rabbit polyclonal; cat. no. 13371-1-AP), and apoptotic protease activating factor (Apaf)-1 (1:1,000; rabbit polyclonal; cat. no. 21710-1-AP) antibodies were from Wuhan Sanying Biotechnology (Wuhan, China); 2',7'-dichlorofluorescin diacetate (DCFH-DA), RNase $\mathrm{H}$ and cytochrome $c(1: 1,000$; mouse polyclonal; cat. no. AC908) were from (Beyotime Institute of Biotechnology, Haimen, China); and goat anti-mouse and goat anti-rabbit secondary antibodies conjugated to horseradish peroxidase were from Sigma-Aldrich; Merck KGaA.

Cell preparation. Human normal liver cell line (LO2) and melanoma cell lines (M14 and A375) were provided by State Key Laboratory of Cellular Stress Biology at the Innovation Center for Cell Biology, (Xiamen University, Xiamen, China). $\mathrm{HaCaT}$ cells were purchased from Shanghai Guan\&Dao Biological Engineering Co., Ltd. (Jinan, China). LO2, HaCaT, M14 and A375 were grown in DMEM supplemented with $10 \%$ FBS and penicillin $(100 \mathrm{U} / \mathrm{ml}) /$ streptomycin $(100 \mu \mathrm{g} / \mathrm{ml})$ in an incubator at $37^{\circ} \mathrm{C}$ and $5 \% \mathrm{CO}_{2}(\mathrm{v} / \mathrm{v})$. In addition, UDCA was dissolved in DMSO to obtain various concentrations $(0,50,10$ $0,150,200,250$ and $300 \mu \mathrm{g} / \mathrm{ml})$.

Cell viability assay. Briefly, M14 cells were seeded at a density of $5 \times 10^{3}$ cells/well in 96 -well microplates at $37^{\circ} \mathrm{C}$ and $5 \% \mathrm{CO}_{2}$ for $24 \mathrm{~h}$, and then the cells were treated with UDCA at different concentrations $(0,50,100,150,200,250$ and $300 \mu \mathrm{g} / \mathrm{ml})$ at $37^{\circ} \mathrm{C}$ for 24,48 and $72 \mathrm{~h}$. Subsequently, $20 \mu \mathrm{l} \mathrm{MTT}$ solution was added to each well followed by incubation at $37^{\circ} \mathrm{C}$ for $4 \mathrm{~h}$. Finally, the culture solution was discarded and $150 \mu 1$ DMSO was added to each well. The absorbance value was detected at a wavelength of $490 \mathrm{~nm}$ using a microplate reader.

Observation of cell morphology changes. A total of $3 \times 10^{5} \mathrm{M} 14$ cells/well were seeded onto the 6 -well coverslips and allowed to adhere at $37^{\circ} \mathrm{C}$ and $5 \% \mathrm{CO}_{2}$ for $12 \mathrm{~h}$ prior to treatment with different concentrations of UDCA $(0,100,200$ and $300 \mu \mathrm{g} / \mathrm{ml})$ at $37^{\circ} \mathrm{C}$ for $48 \mathrm{~h}$. Subsequently, cells were washed with PBS three times and stained with $\mathrm{AO} / \mathrm{EB}$ at room temperature for $10 \mathrm{~min}$. Finally, the cells were washed twice followed by observation under fluorescence microscopy (magnification, x200). In addition, M14 cells were washed with PBS, fixed with methanol at room temperature for $10 \mathrm{~min}$, stained with Hoechst 33258 at room temperature for $7 \mathrm{~min}$ and observed under fluorescence microscopy (magnification, $\mathrm{x} 200$ ).

Cell colony formation assay. M14 cells were seeded into 6-cm plates (500 cells/plate) and allowed to adhere at $37^{\circ} \mathrm{C}$ and $5 \%$ $\mathrm{CO}_{2}$ for $12 \mathrm{~h}$. The old medium was then discarded and different concentrations of UDCA $(0,100200$, and $300 \mu \mathrm{g} / \mathrm{ml})$ was added at $37^{\circ} \mathrm{C}$ and $5 \% \mathrm{CO}_{2}$ for $48 \mathrm{~h}$. Subsequently, the medium containing UDCA was discarded, and cells were allowed to culture in new media for two weeks. Finally, the cells were fixed with anhydrous ethanol at room temperature for $15 \mathrm{~min}$ followed by washing with PBS twice, stained with Giemsa at room temperature for $15 \mathrm{~min}$, washed with PBS twice, photographed and colonies were counted manually.

Cell migration assay. M14 cells were cultured at $37^{\circ} \mathrm{C}$ in $5 \%$ $\mathrm{CO}_{2}(\mathrm{v} / \mathrm{v})$ until the cells covered the entire bottom of the 6 -well plate. The old medium was discarded and a small $10-\mu 1$ white pipette was used to draw an artificial wound area at the bottom of the dish. Following treatment with different concentrations of $\operatorname{UDCA}(0,100,200$, and $300 \mu \mathrm{g} / \mathrm{ml})$ at $37^{\circ} \mathrm{C}$ and $5 \% \mathrm{CO}_{2}$ for $48 \mathrm{~h}$, the cells were washed, then fixed in pure methanol at room temperature for $10 \mathrm{~min}$. The wounds were photographed under inverted ordinary phase-contrast microscopy (TE2000-U; Nikon Corporation, Tokyo, Japan) equipped with NIS-Elements (Nikon Corporation; magnification, x200).

Cell cycle distribution analysis. A total of $3 \times 10^{5} \mathrm{M} 14$ cells/well were seeded onto 6 -well plates and allowed to adhere at $37^{\circ} \mathrm{C}$ and $5 \% \mathrm{CO}_{2}$ for $12 \mathrm{~h}$ and following treatment with different concentrations of $\operatorname{UDCA}(0,100,200$, and $300 \mu \mathrm{g} / \mathrm{ml})$ for $48 \mathrm{~h}$, cells were collected by centrifuging at $1,500 \mathrm{x}$ g at $4^{\circ} \mathrm{C}$ for $10 \mathrm{~min}$ and the precipitations were washed once with PBS. The cells were fixed with a pre-cooled ethanol-PBS mixture $(7: 3, \mathrm{v} / \mathrm{v})$ at $4^{\circ} \mathrm{C}$ for $60 \mathrm{~min}$ and washed twice with PBS. Finally, $10 \mathrm{mg} / \mathrm{ml}$ RNase and $1 \mathrm{mg} / \mathrm{ml}$ PI was added followed by incubating at $37^{\circ} \mathrm{C}$ for $30 \mathrm{~min}$ in the dark. Following filtration of the cells with a 300-mesh sieve, the cells were detected by flow cytometry and processed using the ModFit LT 3.3 (Verity Software House, Inc., Topsham, ME, USA) analysis software. 
Cell apoptosis rate analysis. The apoptosis rate was measured using the Annexin V-FITC/PI Apoptosis Detection kit. M14 cells were seeded using DMEM at a density of $5 \times 10^{3}$ cells/well in 6-well microplates at $37^{\circ} \mathrm{C}$ and $5 \% \mathrm{CO}_{2}$ for $24 \mathrm{~h}$, and then the cells were treated with UDCA at different concentrations $(0,100,200$, and $300 \mu \mathrm{g} / \mathrm{ml})$ at $37^{\circ} \mathrm{C}$ for $48 \mathrm{~h}$., cells were collected and then washed once with PBS; $195 \mu$ l binding buffer (1X) and $5 \mu \mathrm{l}$ Annexin V-FITC was then added to each sample, which were then incubated at $37^{\circ} \mathrm{C}$ for $15 \mathrm{~min}$. Following centrifugation at $1,500 \mathrm{x} \mathrm{g}$ at $4^{\circ} \mathrm{C}$ for $5 \mathrm{~min}, 200 \mu \mathrm{l}$ binding buffer (1X) was added to each tube to wash; subsequently, $190 \mu \mathrm{l}$ binding buffer (1X) and $10 \mu \mathrm{l}$ PI solution was added to each tube to resuspend the cells, and incubated at room temperature for $15 \mathrm{~min}$. The cell apoptosis rate was measured by a FC500 flow cytometer (Beckman Coulter, Inc., Brea, CA, USA) within $4 \mathrm{~h}$, and the data was analyzed using FCS analysis software (Beckman Coulter, Inc.).

Mitochondrial membrane potential ( $\Delta \Psi i)$ analysis. The mitochondrial membrane potential changes in treated cells which were seeded using DMEM at a density of $5 \times 10^{3}$ cells/well in 96-well microplates at $37^{\circ} \mathrm{C}$ and $5 \% \mathrm{CO}_{2}$ for $24 \mathrm{~h}$ and following by UDCA treatment $(0,100,200$, and $300 \mu \mathrm{g} / \mathrm{ml})$ were measured using a mitochondrial membrane potential assay kit (JC-1). The cells were washed with PBS once, and $500 \mu \mathrm{l}$ culture medium was added to each tube to resuspend the cells. An equal volume of JC-1 working fluid was added and the tube was inverted several times. The cells were incubated at $37^{\circ} \mathrm{C}$ and $5 \% \mathrm{CO}_{2}(\mathrm{v} / \mathrm{v})$ for $20 \mathrm{~min}$ and washed twice with JC-1 staining buffer (1X). The cells were resuspended in JC-1 staining buffer $(1 \mathrm{X})$ at room temperature for $5 \mathrm{~min}$ and the intracellular mitochondrial membrane potential was detected using a FC500 flow cytometer (Beckman Coulter, Inc.) and the data was analyzed using FCS analysis software.

Reactive oxygen species (ROS) analysis. A total of $3 \times 10^{5}$ M14 cells /well were seeded onto the 6-well plates and allowed to adhere at $37^{\circ} \mathrm{C}$ and $5 \% \mathrm{CO}_{2}$ for $12 \mathrm{~h}$, following treatment with different concentrations of UDCA $(0,100,200$, and $300 \mu \mathrm{g} / \mathrm{ml})$ for $48 \mathrm{~h}, \mathrm{M} 14$ cells were centrifuged at 3,000 x g at $4^{\circ} \mathrm{C}$ for 5 min, and the pellet was washed once with PBS. Subsequently, $500 \mu 10 \mathrm{mmol} / 1 \mathrm{DCFH}-\mathrm{DA}$ was added to each tube, and the cells were resuspended and incubated at $37^{\circ} \mathrm{C}$ in $5 \% \mathrm{CO}_{2}(\mathrm{v} / \mathrm{v})$ for $20 \mathrm{~min}$. Cells were then centrifuged at $1,500 \mathrm{x}$ at $4^{\circ} \mathrm{C}$ for $5 \mathrm{~min}$ and the supernatant was discarded. Finally, the cells were filtered through a 300-mesh sieve and active oxygen content was determined by a FC500 flow cytometer (Beckman Coulter, Inc.) and the data was analyzed using WinMDI 2.9 (The Scripps Research Institute, La Jolla, CA, USA).

Z-VAD-FMK treatment. M14 cells were plated in 6-well plates as described above, but treated with UDCA $(300 \mu \mathrm{g} / \mathrm{ml})$ and Z-VAD-FMK (40 $\mu \mathrm{M})$ alone or in combination. Then the morphological changes of these cells were observed and changes in apoptosis rate were detected as described above.

Western blot analysis. M14 cells were plated in 6-well plates as described above following treating M14 cells with UDCA $(0,100,200$, and $300 \mu \mathrm{g} / \mathrm{ml})$ at $37^{\circ} \mathrm{C}$ and $5 \% \mathrm{CO}_{2}$ for $48 \mathrm{~h}$, the cells were collected and washed twice. Proteins were extracted with RIPA buffer and centrifuged at $20,000 \mathrm{x}$ g for $30 \mathrm{~min}$ at $4^{\circ} \mathrm{C}$. Total protein concentration was determined using the bicinchoninic acid assay protein assay kit (Beyotime Institute of Biotechnology). Subsequently, the same amount of protein lysates (50 ug/lane) added with loading buffer were separated by $10 \%$ SDS-PAGE, which were then transferred onto polyvinylidene difluoride (PVDF) membranes. The PVDF membranes were blocked with $5 \%$ fat-free milk at $4^{\circ} \mathrm{C}$ for $1 \mathrm{~h}$. Soon afterwards, the membrane was incubated with the specific primary antibodies (diluted with $\mathrm{ddH}_{2} \mathrm{O}$ to $1: 1,000$ ) at $4^{\circ} \mathrm{C}$ overnight, and then proteins were visualized with horseradish peroxidase-coupled secondary antibodies $(1: 10,000)$ at room temperature for $1 \mathrm{~h}$. Finally, the results were detected using an enhanced chemiluminescence kit (Pierce; Thermo Fisher Scientific, Inc.).

Observation of mitochondria with transmission electron microscopy (TEM). A total of $3 \times 10^{5} \mathrm{M} 14$ cells/well were seeded onto the 6-well plates with DMEM and allowed to adhere at $37^{\circ} \mathrm{C}$ and $5 \% \mathrm{CO}_{2}$ for $12 \mathrm{~h}$, following $48 \mathrm{~h}$ of UDCA treatment $(0,100,200$, and $300 \mu \mathrm{g} / \mathrm{ml})$ of M14 cells, cells were collected and washed, and then fixed in $4 \%$ formaldehyde at $4^{\circ} \mathrm{C}$ for 2-3 h. Next, the specimens were cut into $4-58-\mathrm{mm}^{3}$ samples. Cell pellets were fixed with $2.5 \%$ glutaraldehyde in $0.1 \mathrm{M}$ cacodylate buffer at $4^{\circ} \mathrm{C}$ for $2 \mathrm{~h}$ followed by washing with PBS, fixed with $1 \%$ osmium tetroxide at $4^{\circ} \mathrm{C}$ for $1 \mathrm{~h}$ and then dehydrated with alcohol and acetone. Samples were embedded at room temperature overnight in spur-resin, then heated to $70^{\circ} \mathrm{C}$ for $9 \mathrm{~h}$ in capsules. Finally, the samples were cut into 70-nm-thick sections using an ultramicrotome, and the specimens were double-stained with uranyl acetate and lead citrate for $10 \mathrm{~min}$ each. The sample was observed and photographed using a transmission electron microscope (magnification, $\mathrm{x} 1,000)$.

Statistical analysis. All presented data were performed at least in triplicate. Data are presented the as mean + standard deviation. Differences between two groups were analyzed using Student's t-test, and one-way analysis of variance followed by Dunnett's multiple comparisons test was applied for more than two groups. $\mathrm{P}<0.05$ was considered to indicate a statistically significant difference.

\section{Results}

UDCA inhibits the proliferation of two human melanoma cell lines and the ability of colony formation. To evaluate the effects of UDCA (Fig. 1A) on proliferation of M14 cells using MTT assays, melanoma M14 cells were treated for 24,48 and $72 \mathrm{~h}$ with different concentrations of UDCA $(0,50$, $100,150,200,250$ and $300 \mu \mathrm{g} / \mathrm{ml})$. The proliferation rate of the treated groups $(150,200,250$ and $300 \mu \mathrm{g} / \mathrm{ml})$ was significantly reduced compared with that of the control group $(0 \mu \mathrm{g} / \mathrm{ml}$ UDCA) as demonstrated in Fig. 1B. With certain concentrations of UDCA $(150,200,250$ and $300 \mu \mathrm{g} / \mathrm{ml})$ for $48 \mathrm{~h}$, the inhibition rates were $25.65,56.60,64.70$ and $75.22 \%$ compared with that of the control group, respectively. However, UDCA caused very little toxicity in human LO2 hepatocytes and the human keratinocyte HaCaT cells at the same concentration, in comparison with M14 cells as demonstrated in Fig. 1C and D. 
A

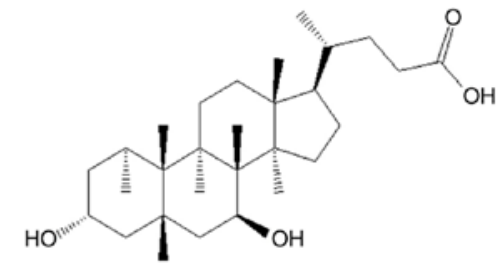

C

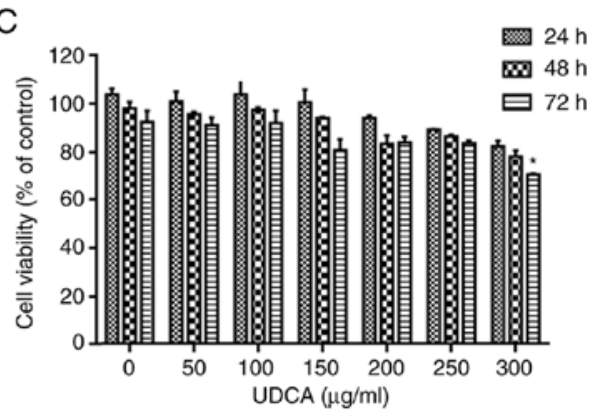

B

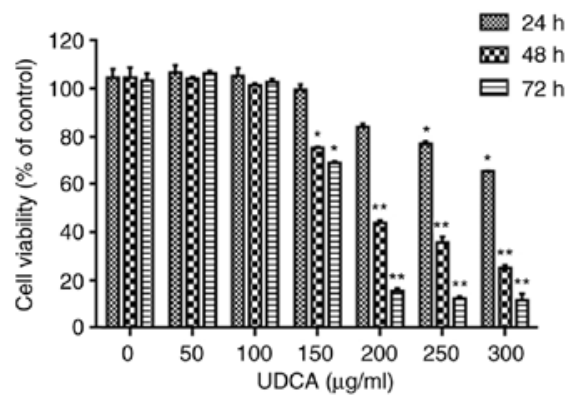

D

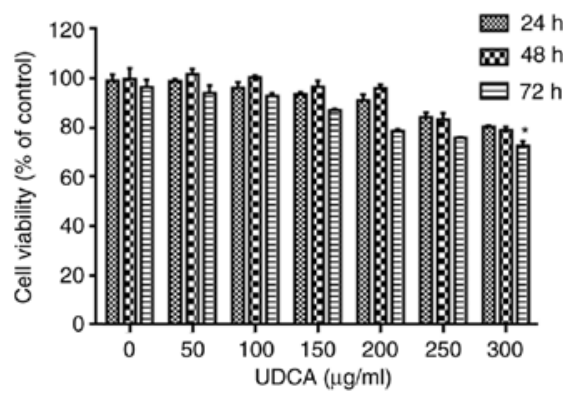

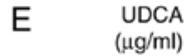

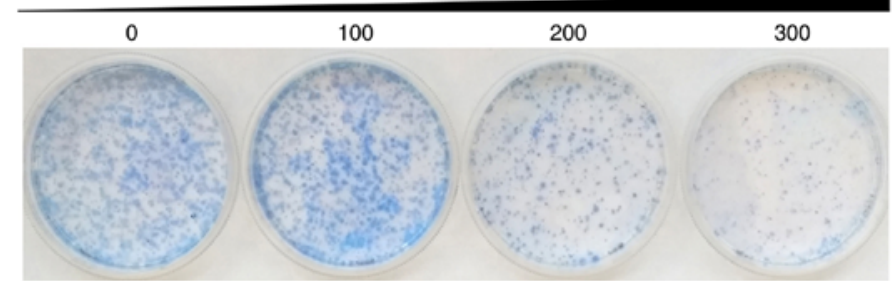

Figure 1. UDCA inhibited cell proliferation and colony-forming ability in M14 cells. (A) The structure of UDCA. (B) Effect of UDCA on the survival rate of M14 cells via MTT assay. (C) Effect of UDCA on the survival rate of LO2 cells using MTT assay. (D) Effect of UDCA on the survival rate of HaCaT cells via MTT assay. (E) The clone-formation of M14 cells treated with different concentrations of UDCA. ${ }^{*} \mathrm{P}<0.05$ and ${ }^{* *} \mathrm{P}<0.01$ as compared with control group. UDCA, ursodeoxycholic acid.

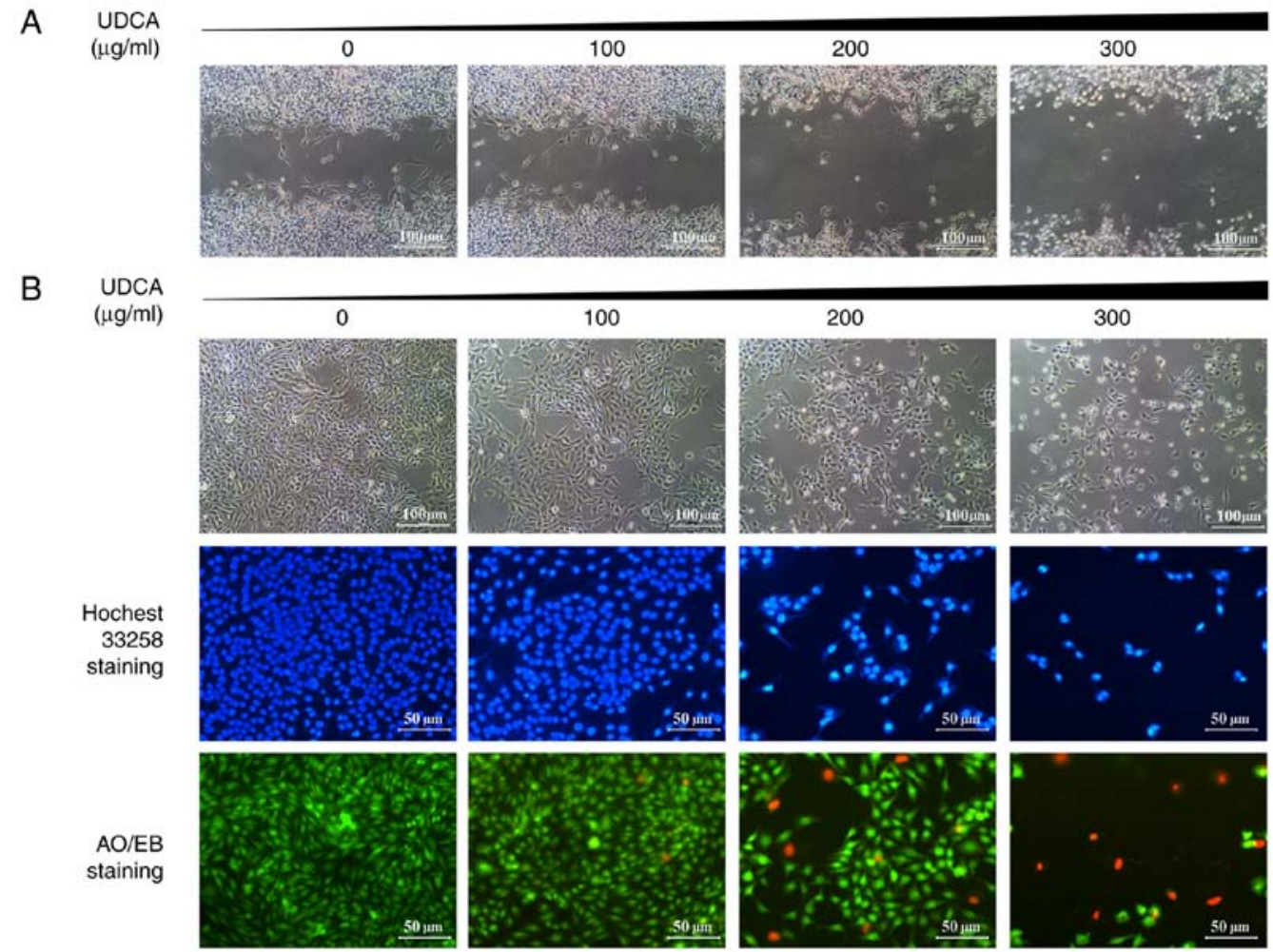

Figure 2. UDCA induced morphological changes in M14 cells. (A) Effects of UDCA on the motility of M14 cells. (B) Morphological changes in M14 cell line treated with UDCA at different concentrations for $48 \mathrm{~h}$ using fluorescence microscopy with AO/EB and Hoechst 33258 staining. UDCA, ursodeoxycholic acid; AO/EB, acridine orange/ethidium bromide. 


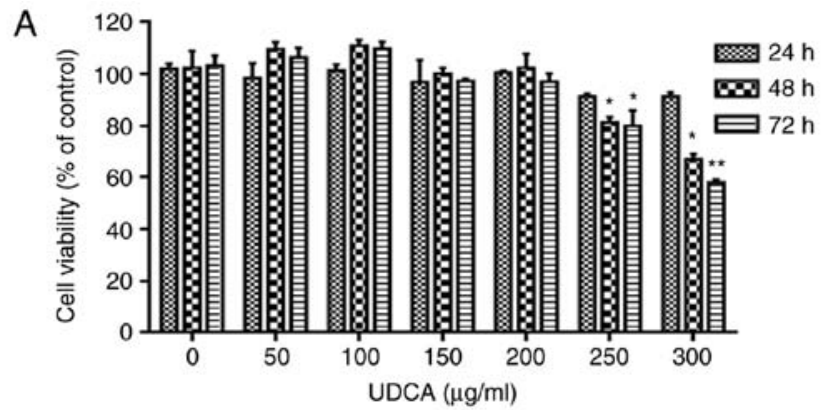

B
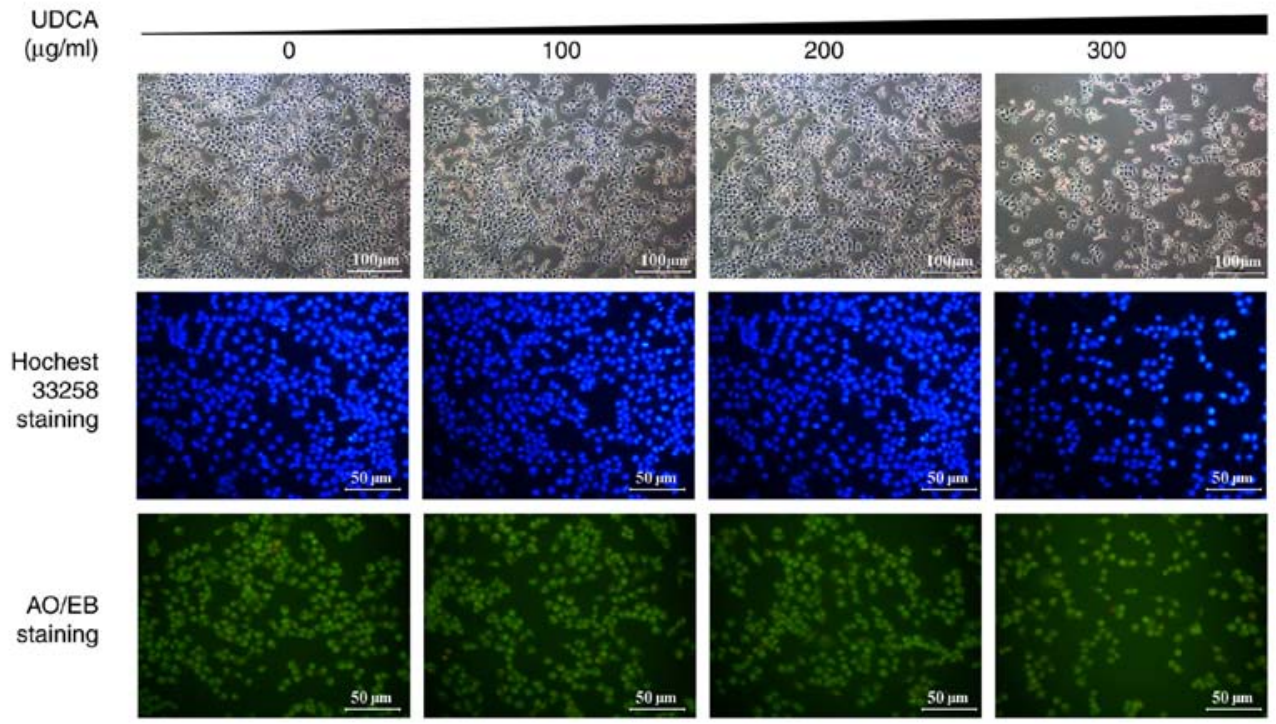

C UDCA $(\mu \mathrm{g} / \mathrm{ml})$
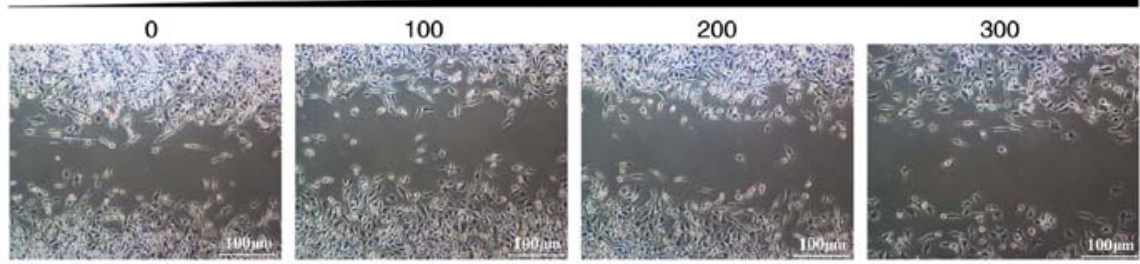

Figure 3. UDCA inhibited cell proliferation, motility ability and induced morphological changes in A375 cells. (A) Effect of UDCA on the survival rate of the M14 cells and A375 cells using MTT assay. ${ }^{*} \mathrm{P}<0.05$ and ${ }^{* *} \mathrm{P}<0.01$ as compared with control group. (B) Morphological changes in A375 cell line treated with UDCA at different concentrations for $48 \mathrm{~h}$ using fluorescence microscopy with AO/EB and Hoechst 33258 staining. (C) Effects of UDCA on the motility of A375 cells. UDCA, ursodeoxycholic acid; AO/EB, acridine orange/ethidium bromide.

To explore whether UDCA could affect the colony-forming ability of M14 cells, 500 M14 cells were seeded into 6-cm plates and then treated with UDCA. As demonstrated in Fig. 1E, when the concentration of UDCA was $100 \mu \mathrm{g} / \mathrm{ml}$, the colony forming ability of M14 cells did not change markedly. However, when the concentration of UDCA was 200 and $300 \mu \mathrm{g} / \mathrm{ml}$, the colony forming ability of M14 cells was markedly decreased. In addition, UDCA could affect the migration ability of M14 cells, as demonstrated in Fig. 2A.

To confirm whether M14 cells undergo morphological changes following UDCA treatment, their morphological characteristics were observed with an optical inverted phase contrast microscope. As demonstrated in Fig. 2B, M14 cells became smaller and more rounded following UDCA treatment compared with the control group. Following Hoechst 33258 staining, the UDCA-treated cells exhibited brighter blue light than that of the control cells, which indicated pyknotic and deep-dyed nuclei. With AO/EB staining, some of the
UDCA-treated M14 cells emitted orange and red fluorescence whose size was smaller compared with the control group.

In addition, UDCA significantly inhibited the proliferation of A375 cells and induced morphological changes following UDCA treatment as demonstrated in Fig. 3A and B. In Fig. 3A, with different concentrations of UDCA (250 and $300 \mu \mathrm{g} / \mathrm{ml}$ ) for $48 \mathrm{~h}$, the inhibition rates were 20.61 and $34.47 \%$ compared with the $0 \mu \mathrm{g} / \mathrm{ml}$ group respectively. In Fig. 3B, A375 cells became smaller and more rounded following UDCA treatment compared with the control group. Following Hoechst 33258 and AO/EB staining, A375 cells exhibited typical morphological changes in apoptosis as in M14 cells. However, UDCA exhibited more evident toxicity in M14 compared with A375 cells at the same concentration and UDCA did not markedly affect the migration of A375 cells (Fig. 3C).

These results indicated that M14 cells exhibited marked apoptosis-associated morphological features and the colony forming ability was decreased following UDCA treatment. 
UDCA inhibits the migration of M14 cells. Wound healing was used to determine whether UDCA could affect the migration ability of M14 cells. The results are presented in Fig. 2A. Following culture for $96 \mathrm{~h}$, cells in the control group quickly migrated to the scratches and the scratches were notably compressed. In the $100 \mu \mathrm{g} / \mathrm{ml}$ group, wounds in the UDCA-treated group were similar to those in the control group; the wounds in the $200 \mu \mathrm{g} / \mathrm{ml}$ group were larger than those in the first two groups and the wounds in the $300 \mu \mathrm{g} / \mathrm{ml}$ group were wider still. However, UDCA did not markedly inhibit the migration of A375 cells at the same concentration in M14 cells (Fig. 3C).

UDCA induces cell cycle arrest in M14 cells. To further explore the role of UDCA in inhibiting the proliferation of M14 cells, flow cytometry was used to detect the cell cycle distribution of M14 cells under different concentrations of UDCA (Fig. 4), by detecting the DNA content of cells (20). M14 cells were stained with PI following $48 \mathrm{~h}$ of UDCA treatment to quantify the DNA content of cells. As revealed in Fig. 4A and C, the percentage of M14 cells in each phase from the control to the UDCA-treatment groups (100, 200, and $300 \mu \mathrm{g} / \mathrm{ml})$, respectively, were as follows: G0/G1 phase, 70, 71, 52 and $68 \%$; $\mathrm{S}$ phase, 25, 22, 32 and 12\%; G2/M phase, 5, 8, 15 and $19 \%$. The percentage of cells in the G2/M phase increased from 5 to $19 \%$ in a dose-dependent manner. This result indicated that UDCA could induce M14 arrest in G2/M phase.

UDCA induces apoptosis in M14 cells. To distinguish the normal, early and late apoptotic cells, flow cytometric analysis was conducted by double staining. In Fig. 4B and D, the results indicated that the apoptosis rate induced by UDCA presented a dose-dependence from $0-300 \mu \mathrm{g} / \mathrm{ml}$. Total proportion of apoptotic cells increased to $12.18 \%$ of $300 \mu \mathrm{g} / \mathrm{ml}$-treatment group from the $1.65 \%$ of the control. These results indicated that UDCA inhibits the growth of M14 cells by inducing apoptosis via activation of caspases.

To further confirm the effect of UDCA on M14 cells by inducing apoptosis, AO/EB and Hoechst 33258 staining were performed to observe the change of cell morphologies. $\mathrm{AO} / \mathrm{EB}$ staining could distinguish apoptotic and necrotic cells with different fluorescence. As demonstrated in Fig. 2B, the control group exhibited a normal morphology and a pale green fluorescence. However, when cells were treated with different concentrations of UDCA, the number of cells gradually decreased and some cells emitted bright green and red fluorescence. When UDCA-treated M14 cells were stained with Hoechst 33258, typical apoptotic features were detected including chromatin condensation and the destructive fragmentation of nuclei as demonstrated in Fig. 2B.

UDCA triggers the generation of ROS in M14 cells. ROS are a by-product of the aerobic metabolism of organisms (21). It has previously been demonstrated that active oxygen is closely associated with tumor formation, cell cycle and apoptosis (22). To detect whether UDCA could induce increased intracellular ROS levels in M14 cells, the intracellular ROS level was examined using flow cytometry (Fig. 5). The mean value of ROS was markedly elevated with the increase of UDCA concentration as demonstrated in Fig. 5A and C. The ROS generation in the $300 \mu \mathrm{g} / \mathrm{ml}$-treatment group increased by $65.27 \%$ compared with the control group, which suggested that the increase of ROS was one of the main factors of apoptosis.

UDCA induces mitochondrial dysfunction in M14 cells. Flow cytometry was used to examine the quantification of $\Delta \Psi \mathrm{m}$ in M14 cells following treatment with UDCA. The decrease in $\Delta \Psi \mathrm{m}$ is a hallmark event in early stages of apoptosis $(23,24)$. JC-1, a fluorescent probe widely used to detect mitochondrial membrane potential, is able to detect cells, tissues and purified $\Delta \Psi \mathrm{m}(25)$. When the $\Delta \Psi \mathrm{m}$ is high, JC-1 in the form of a polymer, accumulates in the matrix of mitochondria, and produces red fluorescence; when the $\Delta \Psi \mathrm{m}$ decreases, JC-1 flows out of the mitochondrial matrix in the form of a monomer, producing green fluorescence (26). Therefore, the degree of mitochondrial depolarization could be quantified by calculating the ratio of red-green fluorescence. As demonstrated in Fig. 5B and D, following M14 cells exposed to UDCA for $48 \mathrm{~h}$, there was a significant increase of the mitochondrial depolarization from 1.5 to $27.5 \%$ at $300 \mu \mathrm{g} / \mathrm{ml}$ compared with the control. The results indicated that each concentration of UDCA could effectively reduce the $\Delta \Psi \mathrm{m}$ with dose-dependence.

Observation of mitochondrial morphology in M14 cells treated with UDCA using TEM. In the present study, UDCA was used to induce melanoma cell apoptosis. As demonstrated in Fig. 6A, mitochondrial morphological changes mainly included two stages: When the concentration was $100 \mu \mathrm{g} / \mathrm{ml}$, the number of mitochondria increased, the distribution was not uniform and some mitochondria began to exhibit dense material deposition; when the concentration was $200 \mu \mathrm{g} / \mathrm{ml}$, mitochondria swelled, and the structure of mitochondria disappeared, leaving only a single layer of film. Nuclear chromatin condensation appeared at $300 \mu \mathrm{g} / \mathrm{ml}$ and adhered to the nuclear membrane to form a wavy curve profile, which was typical of apoptotic cells (27). Therefore, during the entire process of apoptosis in the present study, the changes in mitochondria preceded that in the nucleus.

Changes in M14 apoptosis rate treated with UDCA and caspase inhibitors (Z-VAD-FMK). The ratio of the apoptotic cells decreased when M14 cells were synchronously treated with UDCA and Z-VAD-FMK (Fig. 6B and C). These morphological observations on apoptosis were consistent with the results of the flow cytometric analysis. The UDCA-induced M14 cell apoptosis ratio could be reduced by the Z-VAD-FMK $(40 \mu \mathrm{M})$ from 12.18 to $6.35 \%$ (Fig. 6C and D).

Western blotting. The expression of CDK1 and cyclinB1 at the proteins level were decreased distinctly as demonstrated in Fig. 7A, which was consistent with the results of the flow cytometry analysis in Fig. 4A and C. In addition, western blotting results demonstrated that the expression of MMP-2 and MMP-9 at the protein levels were markedly decreased following UDCA treatment compared with the $0 \mu \mathrm{g} / \mathrm{ml}-\mathrm{UDCA}$ group (Fig. 7B), which was consistent with the results of wound healing analysis in Fig. 2A. PARP1 protein is a marker of apoptosis, which was activated immediately by cleaved-caspase. The activation of $\mathrm{p} 53$, the release of cytochrome $c$ and the cleavage of caspase- 3 and PARP1 were increased in a dose-dependent manner as 

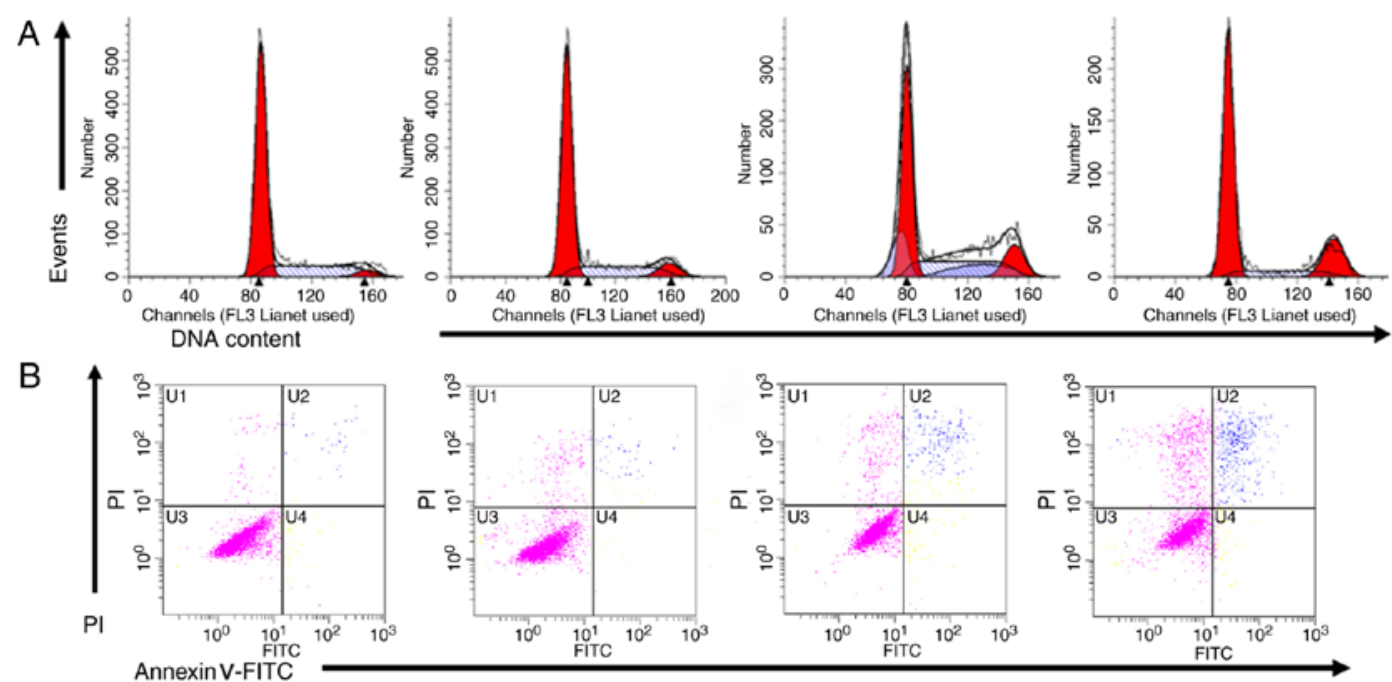

C
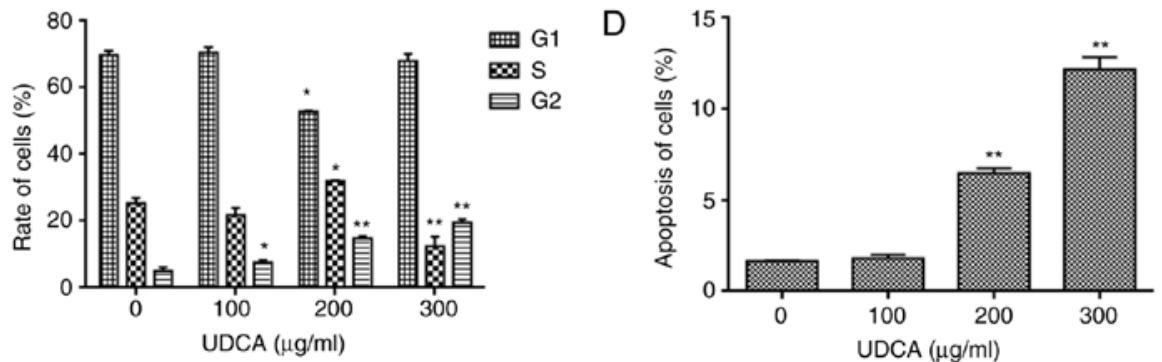

Figure 4. Cell cycle distribution changes and apoptosis induced in M14 cell line by UDCA. (A) Cell cycle distribution changes induced in M14 cell line by UDCA at different concentrations $(0,100,200$ and $300 \mu \mathrm{g} / \mathrm{ml})$ for $48 \mathrm{~h}$. The cells were stained with PI, and cell cycle distribution changes in the cell cycle were detected by flow cytometry. (B) Flow cytometric analysis of cell apoptosis rates in M14 cells. (C) The quantification of cell cycle distribution in each phase. (D) The quantification of the apoptosis cell ratio. One representative experiment out of three is presented. ${ }^{*} \mathrm{P}<0.05,{ }^{* *} \mathrm{P}<0.01$ as compared with control group. UDCA, ursodeoxycholic acid; PI, propidium iodide; FITC, fluorescein isothiocyanate.
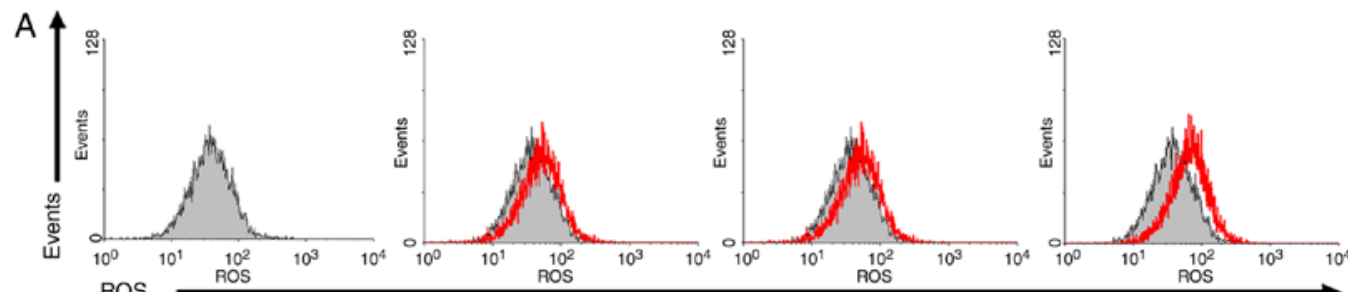

$$
\text { ROS }
$$

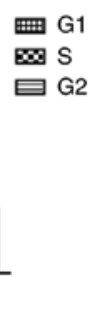

B

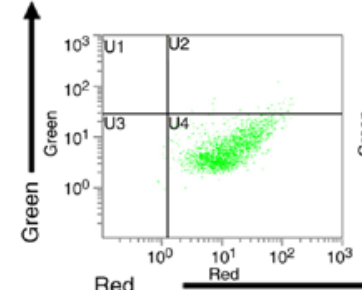

C

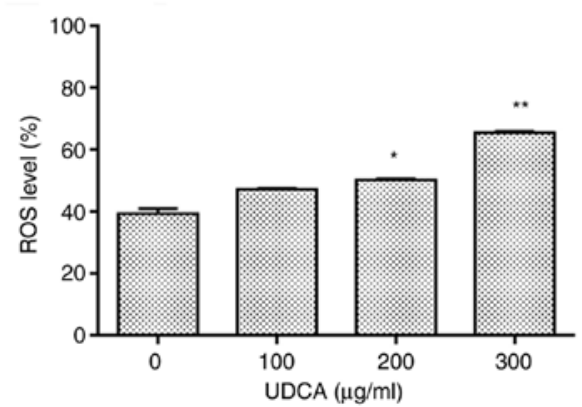

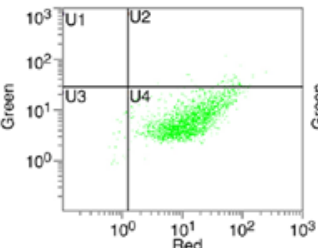
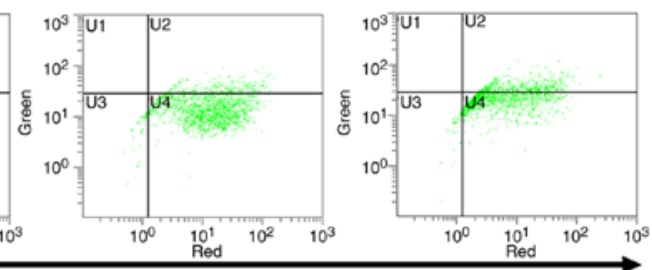

D

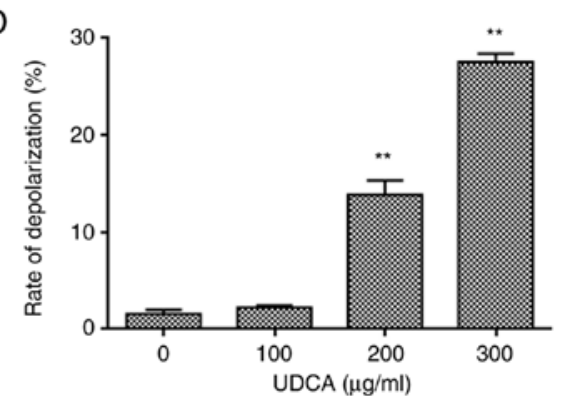

Figure 5. UDCA increases intracellular ROS levels and induces $\triangle \Psi$ m collapse in M14 cells (A) M14 cells were incubated with UDCA. The changes of the ROS level were examined by flow cytometry. (B) Cells were treated with UDCA. Changes in $\Delta \Psi$ m were examined by flow cytometry. (C) The quantification of intracellular ROS levels of cells. (D) The quantification of mitochondrial depolarization. One representative experiment out of three is presented. * $<0.05$, ${ }^{* *} \mathrm{P}<0.01$ as compared with the control group. UDCA, ursodeoxycholic acid; ROS, reactive oxygen species; $\Delta \Psi \mathrm{m}$, mitochondrial membrane potential. 
A

$\underset{(\mu \mathrm{g} / \mathrm{ml})}{\mathrm{UDCA}}$
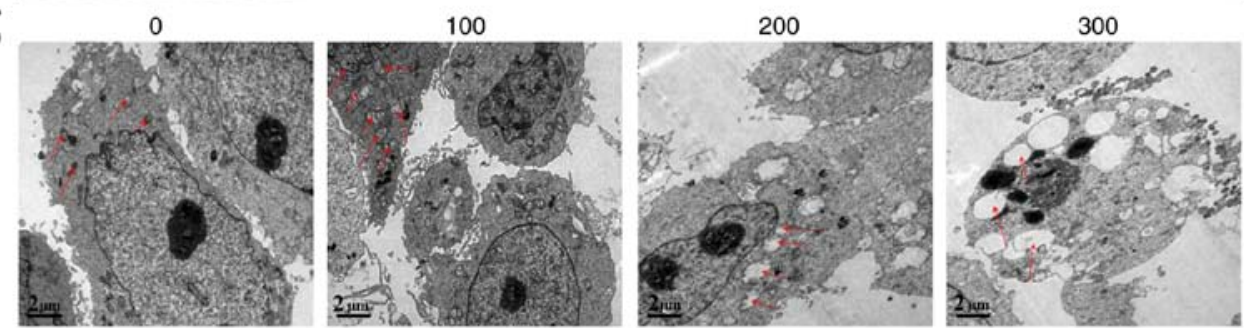

B
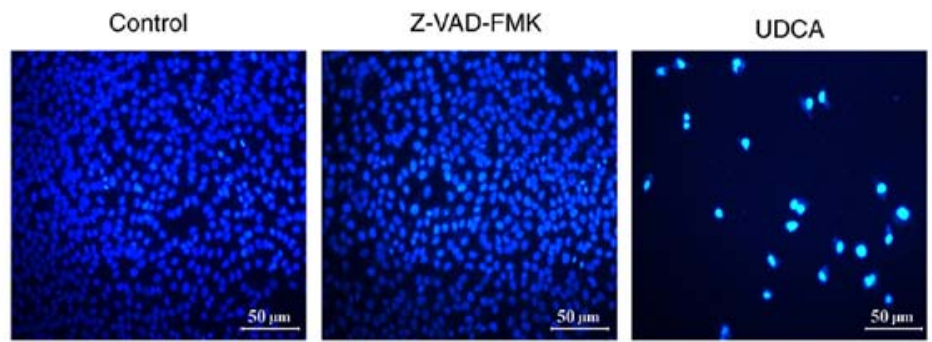

UDCA+Z-VAD-FMK

C
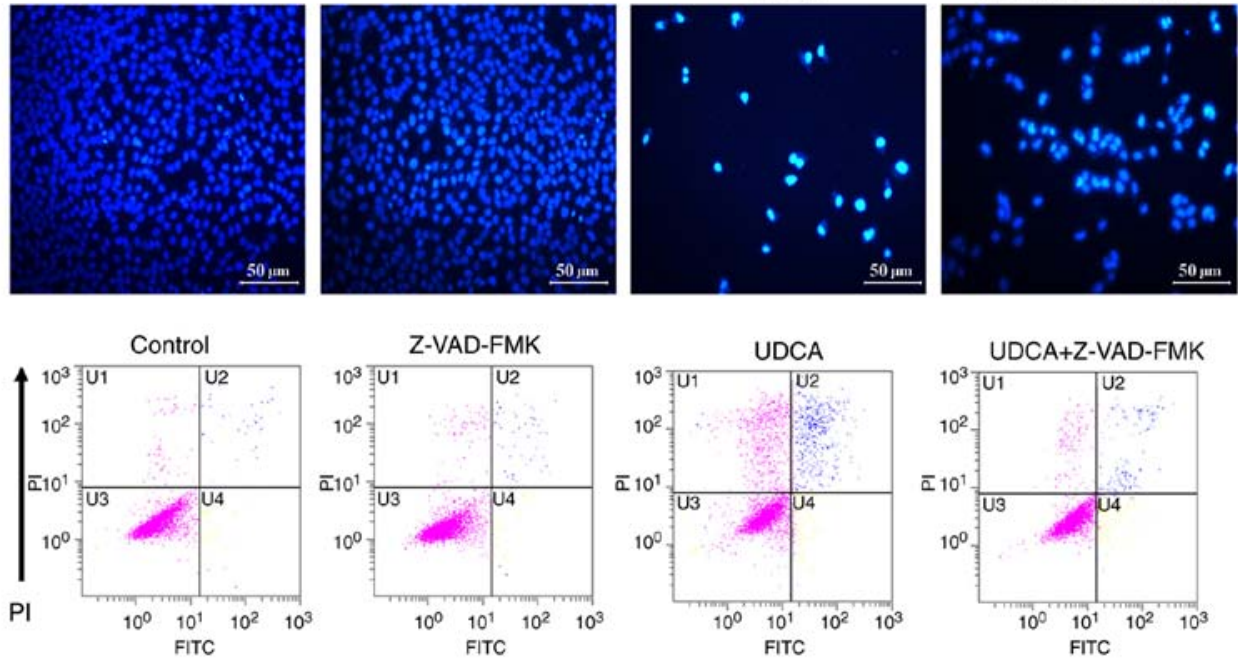

Annexin V-FITC

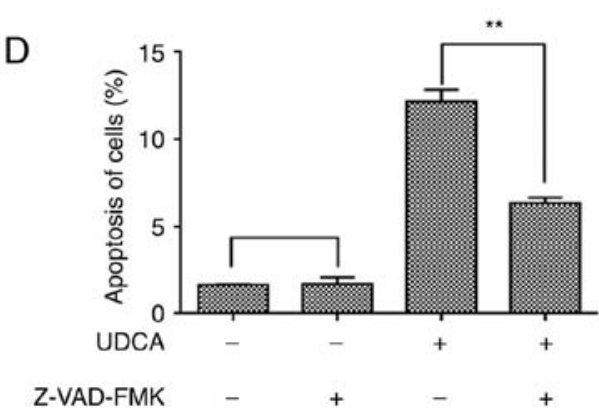

Figure 6. Transmission electron microscopy to observe morphological changes of mitochondria and the effect of the caspase inhibitor Z-VAD-FMK on apoptotic changes in M14 cells treated with UDCA. Cells were treated with $300 \mu \mathrm{g} / \mathrm{ml}$ UDCA in the presence or absence of $40 \mu \mathrm{M} Z$ Z-VAD-FMK. (A) Cells were observed under transmission electron microscopy. Red arrows indicate the location of mitochondria. (B) Morphological apoptotic changes in M14 cells stained with Hoechst 33258. (C) Flow cytometric analysis of apoptosis ratio. (D) The quantification of the apoptosis cell ratio. One representative experiment out of three is presented. ${ }^{* *} \mathrm{P}<0.01$. UDCA, ursodeoxycholic acid; PI, propidium iodide; FITC, fluorescein isothiocyanate.

demonstrated in Fig. 7C-E. Cytochrome $c$ in cytoplasm gradually increased with UDCA treatment, which demonstrated that cytochrome $c$ was gradually released from the mitochondria into cytoplasm (Fig. 7E). In addition, the ratio of Bax/Bcl-2 serves an important role in regulating apoptosis, which was demonstrated in Fig. 7A. Finally, the results of all protein molecule expression changes are summarized in Fig. 7F.

\section{Discussion}

The efficacy of UDCA in primary biliary cirrhosis has been identified previously (28). UDCA is able to improve a series of biochemical and histological parameters (prothrombin time, alkaline phosphatase, alanine transaminase, fatigue, hepatomegaly or splenomegaly) induced by primary biliary cirrhosis, thereby prolonging the patient's survival (29). It has previously been reported that UDCA could effectively induce apoptosis in liver cancer, gastric cancer and colon cancer cell lines (7,30-32). However, to the best of our knowledge the role of UDCA in human melanoma has not yet been explored. The present study investigated the effect of UDCA on the proliferation and apoptosis of human melanoma cell lines to observe its mechanism of the effects. The present data demonstrated that UDCA could significantly inhibit the growth of human melanoma M14 and A375 cells, but the inhibitory effect on LO2 human normal liver cells and the human keratinocyte cells $\mathrm{HaCaT}$ in the same concentration for comparison was not obvious. However, a number of other chemotherapeutic drugs currently in use have many side effects, such as ipilimumab, nivolumab and pembrolizumab $(11,12,33)$.

LO2 is a human normal liver cell. In the present study, LO2 cells were selected as the cultured cell representing 
A
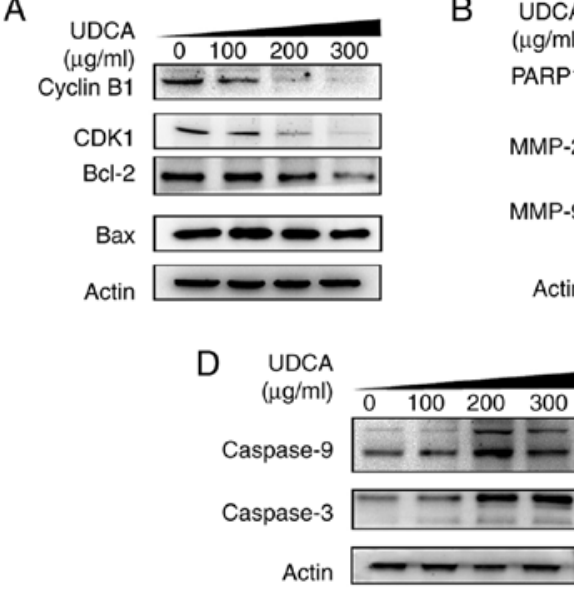

B

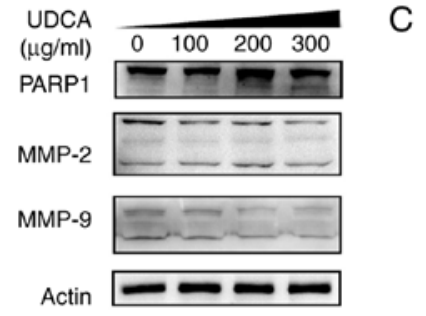

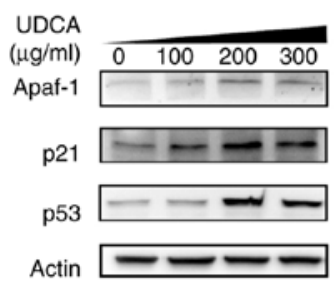

$\mathrm{F}$
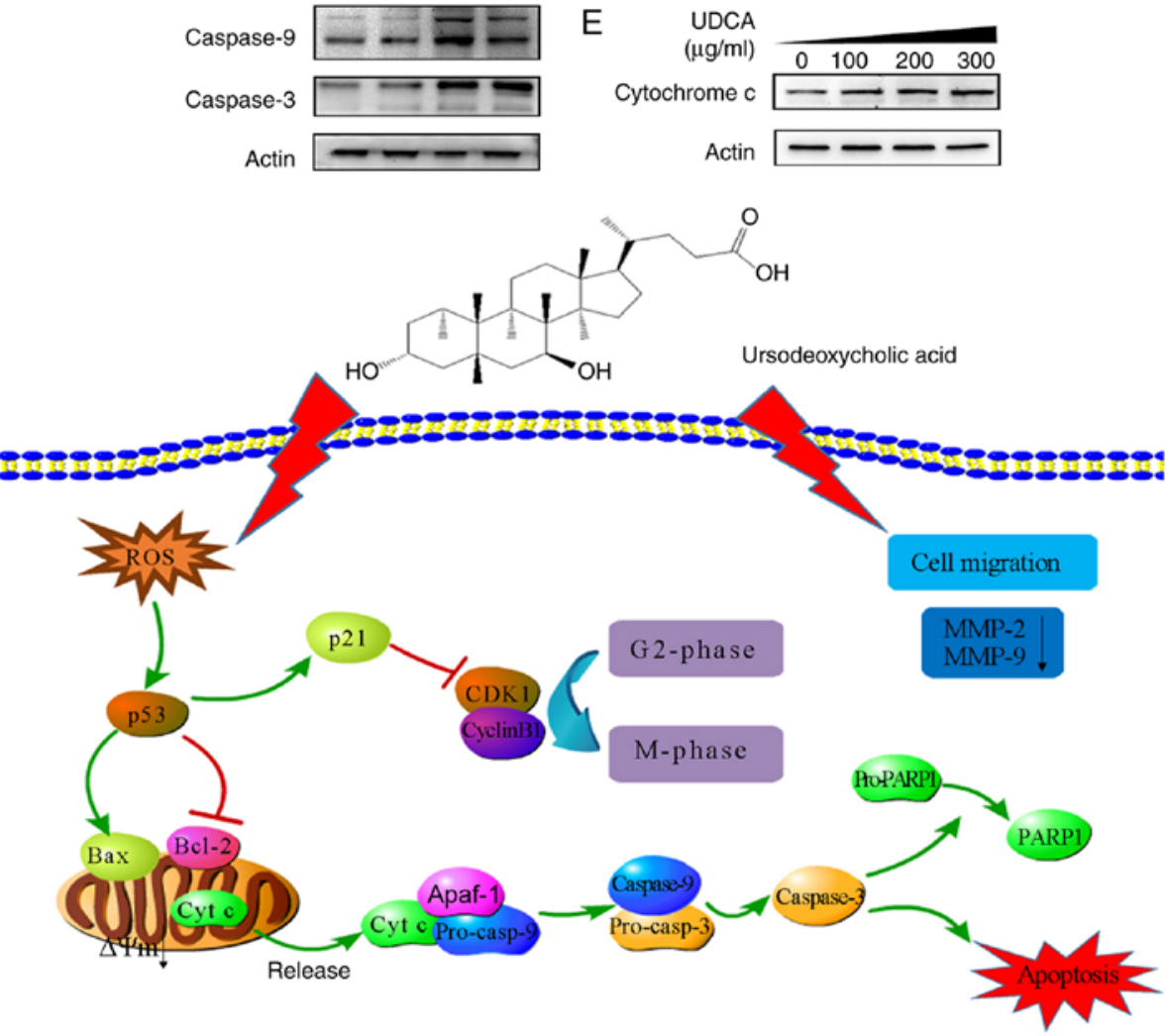

Figure 7. Western blotting results and the illustration of apoptotic signaling induced by UDCA in human melanoma M14 cells. (A-D) Western blotting results of M14 cell protein changes following treatment with UDCA. (E) Western blotting results of M14 cell cytosol protein changes following treating with UDCA. (F) Signaling pathway of apoptosis of M14 cells induced by UDCA. UDCA, ursodeoxycholic acid; CDK, cyclin-dependent kinase; MMP, matrix metalloproteinase; PARP, poly (ADP-ribose) polymerase; Apaf, apoptotic protease activating factor; Bcl-2. B cell lymphoma-2; Bax, Bcl-2 associated x protein; ROS, reactive oxygen species, $\Delta \Psi \mathrm{m}$, mitochondrial membrane potential.

tissue from the biggest digestive gland, the liver, where $90 \%$ of drugs are metabolized by cytochrome P450 enzymes (34) with the majority of them producing efficacy or toxicity afterwards (35). In addition, the liver is very sensitive to xenobiotics and is subject to damage by drug doses several times lower than that which damages other organ tissues (36). In addition, the results of the MTT assay for detecting the inhibitory effect of UDCA on $\mathrm{HaCaT}$ cells at different time points demonstrated that UDCA was specific for the inhibition of M14 cells.

To the best of our knowledge, the present study is the first to explore the mechanism of UDCA-induced apoptosis in M14 cells. It has been reported that there are two primary methods of cell death: Apoptosis and cell necrosis. The present results demonstrated that UDCA could significantly inhibit the proliferation of M14 and A375 cells but caused little toxicity in LO2 and $\mathrm{HaCaT}$ cells. In addition, UDCA had more evident toxicity in M14 compared with A375 cells at the same concentration. Therefore, the mechanism of UDCA induced apoptosis in M14.
The present experiments further confirmed that UDCA could inhibit cell growth by inducing cell cycle arrest and cell apoptosis in M14 cells. In cancer, controlling cell cycle is an effective way to inhibit tumor growth. The present results demonstrated that UDCA arrested the cell cycle of M14 cells in the G2/M phase by downregulating the key factor CDK1 and cyclinB1 proteins (37). These data indicated that the periodic block of M14 by UDCA was an important signaling pathway for its anti-proliferative effect. The present Annexin V-FITC/PI staining results clearly demonstrated that the rate of apoptosis induced by UDCA was dose-dependent. At the same time, in order to further confirm that UDCA could promote cell apoptosis, a series of morphological changes in M14 cells were detected. A series of morphological changes including a change from the shuttle-type to irregular polygon- or round-shaped, chromosome condensation, deepening of staining, nuclear debris and apoptotic bodies, was consistent with the results of flow cytometry analysis. These morphological changes are 
also typical features of apoptosis $(38,39)$, thus UDCA might induce M14 cell death by apoptosis.

Apoptosis comprises two pathways, including the mitochondria-mediated inward apoptotic pathway and the death receptor-mediated external apoptotic pathway (39). Mitochondrial dysfunction is the initial step in the intrinsic apoptotic pathway (40). In addition, $\Delta \Psi \mathrm{m}$ arises from respiration. The electron transport chain pumping protons out of the inner membrane is a key step in the production of ATP (41). Therefore, changes in $\Delta \Psi \mathrm{m}$ have been considered as one of the hallmark events of early apoptosis. In mitochondrial endogenous apoptotic pathways, cells are subjected to external stimuli resulting in changes in $\Delta \Psi \mathrm{m}$, which in turn leads to an increase in apoptosis-associated proteins and cytochrome $c$ release-related proteins (19). Finally, cytochrome $c$ binds to Apaf-1 and this formed protein complex initiates apoptosis by activating downstream caspase. In the present study, the results of flow cytometry indicated that UDCA at all concentrations could effectively reduce $\Delta \Psi \mathrm{m}$. With the increased concentration of UDCA, the degree of mitochondrial depolarization increased gradually. Changes in the $\Delta \Psi \mathrm{m}$ could lead to changes in the conformation of the permeability transition pore, which in turn led to changes in the mitochondrial structure. This structural damage induced the release of cytochrome $c$.

ROS are a by-product of the aerobic metabolism of organisms. Previous studies have demonstrated that active oxygen is closely associated with tumor formation, cell cycle and apoptosis. The present results demonstrated that intracellular ROS levels were significantly increased following UDCA treatment. It was previously indicated that intracellular ROS accumulation is strongly associated with apoptosis (42). Once the accumulation of ROS in the cell reaches a certain level, it will lead to mitochondrial dysfunction and p53 activation which serves a vital role in cell apoptosis (43). The present western blotting results demonstrated that $\mathrm{p} 53$ protein was significantly upregulated with increasing UDCA concentration. This indicated that the accumulation of ROS induced the activation of p53 and led to the apoptosis of M14 cells. It has been reported that Bax and Bcl-2 proteins are important members of $\mathrm{Bcl}-2$ family proteins, of which the former has a pro-apoptotic effect, and the latter has an inhibitory effect on apoptosis (44). In addition, Bax protein is an important transcriptional target of p53 protein (45). In addition, Bax protein promotes the release of cytochrome $c$ from mitochondria into cytosol to active caspase- 3 and finally, the cleavage of caspase-3 leads to cleavage of PARP1, which leads to cell apoptosis (40). In the present study, the protein expression level of Bax was not markedly amended, but the protein expression level of Bcl-2 had decreased, and the cleavage of PARP1 was elevated significantly, which demonstrated that UDCA regulated M14 apoptosis via elevating the ratio of $\mathrm{Bax} / \mathrm{Bcl}-2$ proteins and caused the elevation of p53 which triggered ROS production. Furthermore, electron microscopic observations revealed that the mitochondrial morphology in M14 cells was markedly changed following treatment with UDCA.

In conclusion, UDCA is a novel active compound that could arrest the M14 cells at the G2/M phase and induce apoptosis through ROS-triggered mitochondrial-associated pathways. Therefore, UDCA might become a potential drug for the treatment of melanoma. However, a limitation of the present study is that it was mainly focused on the effect of UDCA in M14 cells; therefore, further studies with A375 and other melanoma cell lines are required.

\section{Acknowledgements}

The present study was supported by the Natural Science Foundation of China (grant nos. 81571418, 81402309 and 81572394), the National Science Foundation for Fostering Talents in Basic Research of the National Natural Science Foundation of China (grant no. J1310027) and by the Natural Sciences Foundation of Fujian Province, China (2016J05105).

\section{Funding}

No funding was received.

\section{Availability of data and materials}

The datasets used during the present study are available from the corresponding author upon reasonable request.

\section{Authors' contributions}

HY and QRF performed the experiments and collected the data. DYS, QW and QXC designed the study, analyzed and interpreted the data, and drafted the manuscript. JYL conducted the western blotting experiments. ZJH conducted the flow cytometry analysis experiments and reviewed the data. All authors have given final approval of the version to be published.

\section{Ethics approval and consent to participate}

Not applicable.

\section{Patient consent for publication}

Not applicable.

\section{Competing interests}

The authors declare that they have no conflict of interest.

\section{References}

1. Kotb MA: Molecular mechanisms of ursodeoxycholic acid toxicity \& side effects: Ursodeoxycholic acid freezes regeneration \& induces hibernation mode. Int J Mol Sci 13: 8882-8914, 2012.

2. Poupon R, Chazouilleres O, Balkau B and Poupon RE: Clinical and biochemical expression of the histopathological lesions of primary biliary cirrhosis. J Hepatol 30: 408-412, 1999.

3. Shah SA, Volkov Y, Arfin Q, Abdel-Latif MM and Kelleher D: Ursodeoxycholic acid inhibits interleukin 1 beta and deoxycholic acid-induced activation of NF-kappaB and AP-1 in human colon cancer cells. Int J Cancer 118: 532-539, 2006.

4. Choi YH, Im EO, Suh H, Jin YG, Yoo YH and Kim ND: Apoptosis and modulation of cell cycle control by synthetic derivatives of ursodeoxycholic acid and chenodeoxycholic acid in human prostate cancer cells. Cancer Lett 199: 157-167, 2003.

5. Feldman RA and Martinez JD: S1646 growth inhibitory effects of ursodeoxycholic acid through negative regulation of receptor tyrosine kinase activity in human colon cancer cells. Gastroenter ology 134: (4 Suppl 1) A-241, 2008.

6. Im E and Martinez JD: Ursodeoxycholic acid (UDCA) can inhibit deoxycholic acid (DCA)-induced apoptosis via modulation of EGFR/Raf-1/ERK signaling in human colon cancer cells. J Nutr 134: 483-486, 2004. 
7. Lim SC and Han SI: Ursodeoxycholic acid effectively kills drug-resistant gastric cancer cells through induction of autophagic death. Oncol Rep 34: 1261-1268, 2015.

8. Crowson AN, Magro CM and Mihm MC (eds): Melanoma. In The Melanocytic Proliferations: A Comprehensive Textbook of Pigmented Lesions. 2nd edition. John Wiley \& Sons, Inc., Hoboken, NJ, pp254-365, 2014.

9. Luo $\mathrm{C}$ and Shen JY: Research progress in advanced melanoma. Cancer Lett 397: 120-126, 2017.

10. Chisholm JC, Suvada J, Dunkel IJ, Casanova M, Zhang W, Ritchie N, Choi Y, Park J, Das Thakur M, Simko S, et al: BRIM-P: A phase I, open-label, multicenter, dose-escalation study of vemurafenib in pediatric patients with surgically incurable, BRAF mutation-positive melanoma. Pediatr Blood Cancer 65: e26947, 2018.

11. Dalvin LA, Shields CL, Orloff M, Sato T and Shields JA Checkpoint Inhibitor Immune Therapy Systemic indications and ophthalmic side effects. Retina 38: 1063-1078, 2018.

12. Hantel A, Gabster B, Cheng JX, Golomb H and Gajewski TF: Severe hemophagocytic lymphohistiocytosis in a melanoma patient treated with ipilimumab plus nivolumab. J Immunother Cancer 6: 73, 2018

13. Agarwal A, Kasinathan A, Ganesan R, Balasubramanian A, Bhaskaran J, Suresh S, Srinivasan R, Aravind KB and Sivalingam N: Curcumin induces apoptosis and cell cycle arrest via the activation of reactive oxygen species-independent mitochondrial apoptotic pathway in Smad4 and p53 mutated colon adenocarcinoma HT29 cells. Nutr Res 51: 67-81, 2018.

14. Hegde M, Vartak SV, Kavitha CV, Ananda H, Prasanna DS Gopalakrishnan V, Choudhary B, Rangappa KS and Raghavan SC: A benzothiazole derivative $(5 \mathrm{~g})$ induces DNA damage and potent G2/M arrest in cancer cells. Sci Rep 7: 2533, 2017.

15. Bi YL, Min M, Shen W and Liu Y: Genistein induced anticancer effects on pancreatic cancer cell lines involves mitochondrial apoptosis, $\mathrm{G}_{0} / \mathrm{G}_{1}$ cell cycle arrest and regulation of STAT3 signalling pathway. Phytomedicine 39: 10-16, 2018.

16. Checchetto V and Szabo I: Novel channels of the outer membrane of mitochondria: Recent discoveries change our view. Bioessays 40: e1700232, 2018.

17. Mao XM, Fu QR, Li HL, Zheng YH, Chen SM, Hu XY, Chen QX and Chen QH: Crocodile choline from Crocodylus siamensis induces apoptosis of human gastric cancer. Tumor Biol 39: 1010428317694320, 2017. doi: 10.1177/1010428317694320.

18. Fu QR, Song W, Deng YT, Li HL, Mao XM, Lin CL, Zheng YH, Chen SM, Chen QH and Chen QX: ESC-3 induces apoptosis of human ovarian carcinomas through Wnt/ $\beta$-catenin and Notch signaling in vitro and in vivo. Int J Oncol 50: 241-251, 2017.

19. Su WC, Lin YF, Yu XP, Wang YX, Lin XD, Su QZ, Shen DY and Chen QX: Mitochondria-associated apoptosis in human melanoma cells induced by cardanol monoene from cashew nut shell liquid. J Agric Food Chem 65: 5620-5631, 2017.

20. Jimenez-Sánchez A: Chromosome replication status and DNA content at any cell age in a bacterial cell cycle. J Theor Biol 380: 585-589, 2015

21. Sundqvist M, Christenson K, Björnsdottir H, Osla V, Karlsson A, Dahlgren C, Speert DP, Fasth A, Brown KL and Bylund J: Elevated mitochondrial reactive oxygen species and cellular redox imbalance in human NADPH-oxidase-deficient phagocytes. Front Immunol 8: 1828, 2017.

22. Kim SY, Kim EK, Jeong AR, Kim YJ, Kim EJ, Cho JH, Park DK, Kwon KA, Chung JW and Kim KO: Tu1829 The effects of ursodeoxycholic acid on cell cycle, reactive oxygen species, and proliferation of colon cancer cell. Gastroenterology 150 (4 Suppl 1): S955, 2016

23. Seol J, Chaudhari A, Kang H, Kim N, Kim I and Park S Gemcitabine sensitizes A549 cells to tumor necrosis factorrelated apoptosis-inducing ligand by up-regulating DR-5 protein and lowering mitochondrial transmembrane potential. Differentiation 74: 468-468, 2006

24. Choi JS, Shin S, Jin YH, Yim H, Koo KT, Chun KH, Oh YT, Lee WH and Lee SK: Cyclin-dependent protein kinase 2 activity is required for mitochondrial translocation of Bax and disruption of mitochondrial transmembrane potential during etoposide-induced apoptosis. Apoptosis 12: 1229-1241, 2007.

25. Yokosuka T, Goto H,Fujii H, Naruto T, Takeuchi M, Tanoshima R, Kato H, Yanagimachi M, Kajiwara R and Yokota S: Flow cytometric chemosensitivity assay using JC-1, a sensor of mitochondrial transmembrane potential, in acute leukemia. Cancer Chemother Pharmacol 72: 1335-1342, 2013.
26. Simeonova E, Garstka M, Koziol-Lipinska J and Mostowska A: Monitoring the mitochondrial transmembrane potential with the JC-1 fluorochrome in programmed cell death during mesophyll leaf senescence. Protoplasma 223: 143-153, 2004

27. He Y,Zhong GQ, Zeng ZY, Li JY, Li W, Li WK and Ke HH: Effect of heptanol on apoptosis and structural changes of mitochondria in ischemia-reperfusion injury of rabbit. Circulation 122: E196, 2010

28. Goel A and Kim WR: Natural history of primary biliary cholangitis in the ursodeoxycholic acid era role of scoring systems. Clin Liver Dis 22: 563-578, 2018.

29. Poupon RE, Bonnand AM, Chretien Y and Poupon R: Ten-year survival in ursodeoxycholic acid-treated patients with primary biliary cirrhosis. Hepatology 29: 1668-1671, 1999.

30. Perez-Holanda S, Rodrigo L, Viñas Salas J and Piñol Felis C: Effect of ursodeoxycholic acid in an experimental colon cancer model. Rev Esp Enferm Dig 99: 491-496, 2007 (In Spanish).

31. Lim S and Han S: Ursodeoxycholic acid induces apoptotic death through activation of ERK1/2 and A-SMase in gastric cancer cells. Virchows Arch 455: 397, 2009.

32. Kim EK, Kim EJ, Cho JH, Park DK, Kwon KA, Chung JW, Kim KO and Kim YJ: The effects of ursodeoxycholic acid on cell cycle, reactive oxygen species, and proliferation of colon cancer cell. Digestion 95: 98, 2017.

33. Becker S, Schilling L, Krecke N, Thurner L, Vogt T and Pföhler C: Autoimmune hemolytic anemia as a rare side effect of pembrolizumab therapy. J Der Deutschen Dermatologischen Gesellschaft 16: 56-57, 2018.

34. Dambach DM, Andrews BA and Moulin F: New technologies and screening strategies for hepatotoxicity: Use of in vitro models. Toxicol Pathol 33: 17-26, 2005.

35. Gomez-Lechon MJ, Castell JV and Donato MT: Hepatocytes-the choice to investigate drug metabolism and toxicity in man: In vitro variability as a reflection of in vivo. Chem Biol Interact 168: 30-50, 2007.

36. Burcham PC: Target-organ toxicity: Liver and kidney. In: An Introduction to Toxicology. Springer, London, pp151-187, 2014.

37. Amin M, Razi M, Sarrafzadeh-Rezaei F, Shalizar Jalali A and Najafi G: Berberine inhibits experimental varicocele-induced cell cycle arrest via regulating cyclin D1, cdk4 and p21 proteins expression in rat testicles. Andrologia: Feb 14, 2018 (Epub ahead of print).

38. Yadav PK, Tiwari M, Gupta A, Sharma A, Prasad S, Pandey AN and Chaube SK: Germ cell depletion from mammalian ovary: Possible involvement of apoptosis and autophagy. J Biomed Sci 25: 36, 2018

39. Marjaneh RM, Hassanian SM, Ghobadi N, Ferns GA, Karimi A, Jazayeri MH, Nasiri M, Avan A and Khazaei M: Targeting the death receptor signaling pathway as a potential therapeutic target in the treatment of colorectal cancer. J Cell Physiol 233: 6538-6549, 2018

40. Alaimo A, Gorojod RM and Kotler ML: The extrinsic and intrinsic apoptotic pathways are involved in manganese toxicity in rat astrocytoma C6 cells. Neurochem Int 59: 297-308, 2011.

41. Fernandez-Cardenas LP, Villanueva-Chimal E, Salinas LS, Jose-Nunez C, Tuena de Gómez Puyou M and Navarro RE: Caenorhabditis elegans ATPase inhibitor factor 1 (IF1) MAI-2 preserves the mitochondrial membrane potential $(\Delta \psi \mathrm{m})$ and is important to induce germ cell apoptosis. PLoS One 12: e0181984, 2017.

42. Ali NM, Yeap SK, Abu N, Lim KL, Ky H, Pauzi AZM, Ho WY, Tan SW, Alan-Ong HK, Zareen S, et al: Synthetic curcumin derivative DK1 possessed G2/M arrest and induced apoptosis through accumulation of intracellular ROS in MCF-7 breast cancer cells. Cancer Cell Int 17: 30, 2017.

43. Sardao VA, Oliveira PJ, Holy J, Oliveira CR and Wallace KB: Doxorubicin-induced mitochondrial dysfunction is secondary to nuclear p53 activation in $\mathrm{H} 9 \mathrm{c} 2$ cardiomyoblasts. Cancer Chemother Pharmacol 64: 811-827, 2009.

44. Barrezueta LF, Oshima CT, Lima FO, De Oliveira Costa H, Gomes TS, Neto RA and De Franco MF: The intrinsic apoptotic signaling pathway in gastric adenocarcinomas of Brazilian patients: Immunoexpression of the Bcl-2 family (Bcl-2, Bcl-x, $\mathrm{Bak}, \mathrm{Bax}, \mathrm{Bad}$ ) determined by tissue microarray analysis. Mol Med Rep 3: 261-267, 2010.

45. Dethlefsen MM, Halling JF, Moller HD, Plomgaard P, Regenberg B, Ringholm S and Pilegaard $\mathrm{H}$ : Regulation of apoptosis and autophagy in mouse and human skeletal muscle with aging and lifelong exercise training. Exp Gerontol 111: 141-153, 2018.

This work is licensed under a Creative Commons Attribution-NonCommercial-NoDerivatives 4.0 International (CC BY-NC-ND 4.0) License. 